\title{
Morking
}

Paper 
China's Path to Consumer-Based Growth:

Reorienting Investment and

Enhancing Efficiency

Il Houng Lee, Murtaza Syed, and Liu Xueyan 


\title{
IMF Working Paper
}

Asia and Pacific Department

\section{China's Path to Consumer-Based Growth: Reorienting Investment and Enhancing Efficiency}

\author{
Prepared by Il Houng Lee, Murtaza Syed and Liu Xueyan ${ }^{1}$
}

Authorized for distribution by Il Houng Lee

March 2013

\section{This Working Paper should not be reported as representing the views of the IMF.} The views expressed in this Working Paper are those of the author(s) and do not necessarily represent those of the IMF or IMF policy. Working Papers describe research in progress by the author(s) and are published to elicit comments and to further debate.

\begin{abstract}
This paper proposes a possible framework for identifying excessive investment. Based on this method, it finds evidence that some types of investment are becoming excessive in China, particularly in inland provinces. In these regions, private consumption has on average become more dependent on investment (rather than vice versa) and the impact is relatively short-lived, necessitating ever higher levels of investment to maintain economic activity. By contrast, private consumption has become more self-sustaining in coastal provinces, in large part because investment here tends to benefit household incomes more than corporates. If existing trends continue, valuable resources could be wasted at a time when China's ability to finance investment is facing increasing constraints due to dwindling land, labor, and government resources and becoming more reliant on liquidity expansion, with attendant risks of financial instability and asset bubbles. Thus, investment should not be indiscriminately directed toward urbanization or industrialization of Western regions but shifted toward sectors with greater and more lasting spillovers to household income and consumption. In this context, investment in agriculture and services is found to be superior to that in manufacturing and real estate. Financial reform would facilitate such a reorientation, helping China to enhance capital efficiency and keep growth buoyant even as aggregate investment is lowered to sustainable levels.
\end{abstract}

JEL Classification Numbers: E22, H4, O14, R11, R12

Keywords: China, Investment, Rebalancing, Regional Economics

Author's E-Mail Addresses: ilee@imf.org; msyed@imf.org; liuxueyan@amr.gov.cn

\footnotetext{
${ }^{1}$ Messrs. Lee and Syed are, respectively, the Senior and Deputy Resident Representative in the IMF's China office. Ms Xueyan is a Senior Fellow in the Academy of Macroeconomic Research at the National Development and Reform Commission (NDRC) of China. We would like to thank Wang Xin for outstanding research assistance, and the NDRC and the People's Bank of China for hosting seminars and providing valuable comments. This paper has also benefitted from comments by the IMF China team.
} 


\section{Contents}

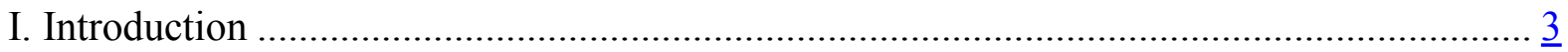

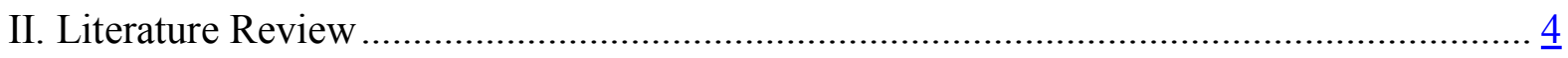

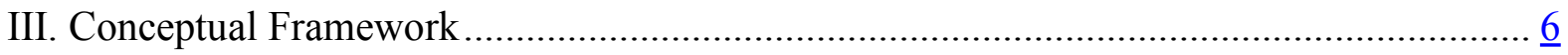

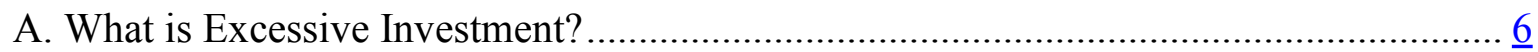

B. Identifying Excessive Investment Empirically ..................................................

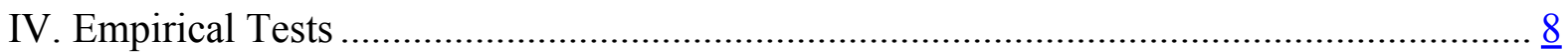

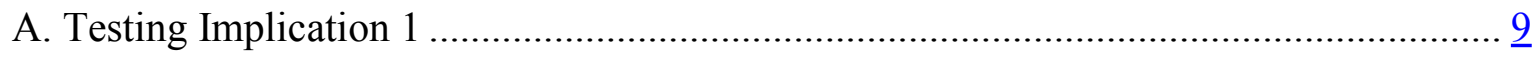

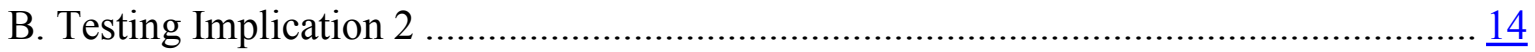

V. What About the Ability to Finance Excessive Investment? ....................................... 16

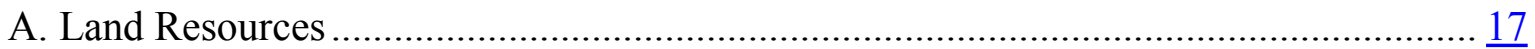

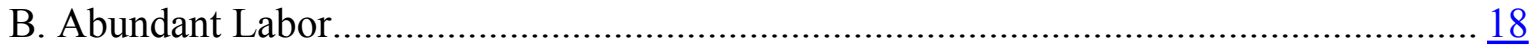
C. Bank Financing ......................................................................................... 18
D. Government Resources .................................................................................... 19

VI. Policy Implications ............................................................................... 20

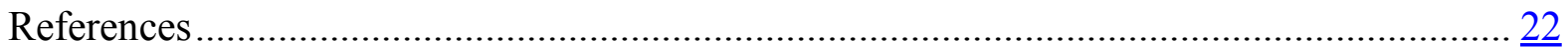




\section{INTRODUCTION}

There seems to be a growing consensus that China's growth model - heavily reliant on exports and investment—may have run its course. Not many challenge that China will have to adjust to slower global trade growth over the next decade. However, views differ on the role of investment. On one side, it is argued that huge infrastructure needs - particularly in less developed non-coastal areas - and ongoing urbanization will require still ample investment. In the other camp, there is some skepticism about whether China can continue to invest at the current rate due to limited absorptive capacity, increasingly inefficient investment and tightening financing conditions.

Assessing which of these views is more appropriate is very important at the current juncture, as China searches for alternative growth engines amid structural changes to its economy and an external landscape transformed by the global crisis. If some investment is excessive, that part will only raise output at the time of implementation, with little impact on future growth. If continued, large deadweight losses will arise that could become increasingly difficult to resolve. On the other hand, cutting investment, even if it is excessive, will inevitably slow growth. The only way to maintain relatively robust growth in this case would be to raise capital efficiency.

Acknowledging this issue, the Chinese government for the first time called for a reduction in "redundant" public investment during its most recent Economic Work Conference. So what kinds of investment should be curtailed? Another way of describing this challenge is how to ensure consumption does not slow too much as investment declines to a lower steady state growth path. Excessive investment will likely raise corporate income, and to a lesser extent household income as the share of labor cost is usually low, during the implementation phase and then falter quickly thereafter as it will not contribute to effective capital accumulation. On the other hand, more efficient investment that contributes to the productive capital stock should have a less direct and less transitory link with corporate and household income. Instead, investment will be associated with a more permanent and higher income, and consumption would be more self-sustaining.

On this basis, this paper reviews trends in investment at the provincial level in China and finds evidence that some types of investment is becoming excessive, especially in inland regions. In these regions, investment Granger-causes consumption on average. By contrast, in coastal provinces, private consumption has on average become more self-sustaining and less dependent on investment. Moreover, in relative terms, investment is more closely associated with higher household income in coastal provinces while in inland provinces it seems to influence corporate income more. This suggests that the share of investment contributing to the productive capital stock in coastal areas is larger than in inland provinces. If this trend is continued, valuable resources are likely to be wasted. Thus, investment should not be indiscriminately directed to urbanization but could be lowered in inland provinces and 
shifted toward sectors with greater and more lasting beneficial spillovers to household income and domestic consumption. In this context, our analysis shows that investment in agriculture and services is likely to be superior to that in manufacturing and real estate. Through such a reorientation, which in turn would require financial sector reform, China can enhance capital efficiency such that economic growth does not fall precipitously as aggregate investment is lowered to more sustainable level.

A few caveats are in order. First, the effects we uncover relate mainly to the most recent period of investment and to the average type of investment. The results do not by any means imply that all types of investment in inland provinces are excessive, or that all investments in coastal provinces are optimal. Indeed, we find that the type of investment model being advocated in broad terms in inland provinces today — with its emphasis on infrastructure and manufacturing - is not very different from that used earlier in coastal regions. This model eventually gained traction in the coastal provinces and helped spur today's more selfsustained consumption there.

However, changes in the global economy as well as differences in the comparative advantage of inland provinces are likely to make the same model less effective in the Center and West of China, and we find some evidence to this effect. Our finding is also consistent with the government's attempt to reduce overcapacity in various industries. Therefore, the model may need to be re-adapted, with some investment reallocated toward sectors that may yield bigger and more lasting payoffs in these regions. For instance, provinces with advantages in agriculture should not indiscriminately be tried to convert into manufacturing bases, and a more varied approach to provincial economic structure and investment, as well as interprovincial trade, is likely to be more fruitful. Second, certain types of investments, including those in public goods or those that have pay-offs over longer horizons or are intended to help bridge inequalities across provinces, fall outside of our framework and could still be undertaken on the basis of social returns. Third, the methodology introduced in the paper is by no means the only one that could be used to identify excessive investment, but it is hoped that it will help to move the debate forward on this vital topic as China attempts to move away from its over reliance on investment.

Ultimately, this paper is an attempt to provide some guidance on how to rebalance China's economy in a way that can maintain a role for investment but in a way that recognizes the changes that have occurred in the global and domestic economy, harnesses the potential offered by China's size and diversity, and generates more lasting benefits for the rest of the economy. In the final analysis, that is what transiting to a new growth model will entail.

\section{Literature ReVIEW}

In a previous paper (Lee et. al (2012)), we argued that China's current levels of aggregate investment appear significantly out of line compared to the experience of other emerging 
markets around their take-off periods. Based on a cross-country panel, we found that this "excess investment" had grown to around 10 percent of GDP and was being financed through a hidden transfer of resources from households and SMEs toward large corporates, amounting to around 4 percent of GDP every year. This paper goes one step further in trying to identify what specific types of investment may be especially excessive, both from a geographical and sectoral perspective. In this way, it is aimed at pin-pointing the forms of capital spending that may not be generating lasting economic returns and which could reasonably be curtailed as China attempts to move toward a more consumer-based model of growth in coming years.

Our paper is related to a few recent studies examining the efficiency of investment across provinces and firm ownership in China. Using a large sample of Chinese firms between 2002-2004, Dollar and Wei (2007) report significantly lower returns to capital in state-owned firms and in Western and inland provinces compared to those along the Eastern coast. Zhang et al. (2012), Xiong (2010) and $\mathrm{Wu}$ (2008) reach a similar conclusion regarding the efficiency of investment across China's provinces using scores based on data envelopment techniques, and a production function approach, respectively. Quantitatively, Wu (2008) finds an investment efficiency score of around 66 percent for China as a whole, but significantly smaller in inland and Western regions.

Other studies also lend support to these views, including Qin and Song (2009), who find that coastal regions are generally more efficient than western ones in terms of capital productivity and Boyreau-Debray and Wei (2004), who estimate the marginal product of capital across provinces in China and report that capital has been diverted to less productive western regions under the government's post-1999 "Go West" development strategy. As a result, they contend that reducing government intervention in the financial sector could yield greater economic payoffs. Bai et al. (2006) also report considerable variation in the return on capital across provinces, with it being highest in the east and lowest in the west of China, but find that it decreased over time at least through 2005.

However, our approach has at least three novel features. First, it includes the period after the onset of the global crisis, where investment has been ratcheted up even further and thus allows an examination of the effectiveness of China's policy response. Second, our approach accounts for the fact that elevated investment can confound traditional measures of investment efficiency like returns to capital and ICORs by temporarily generating high levels of growth that may not be sustained. Instead, we build a framework that allows us to establish the excessiveness of investment by studying its links with consumption and incomes. Third, we go beyond most of the existing literature by assessing not just the variation in capital efficiency across provinces but also by sector. In this way, our paper speaks directly to the current policy dilemma of how to identify excessive areas of investment, how to focus attention toward capital projects that generate greater and more lasting impacts on economic activity, and how best to ensure that growth remains robust even 
as China moves away from an investment-led strategy to one that places more emphasis on private consumption, in line with the Chinese government's objectives.

\section{Conceptual Framework}

\section{A. What is Excessive Investment?}

One way to assess the impact of investment on growth is to examine whether investment adds value to the capital stock. If investment does not add value in terms of creating a future flow of goods and services (i.e., the value added concept of national accounts), then that part of investment will not contribute to the productive capital stock. It will initially be captured as excess capacity and then, once depreciation sets in, as wasted. Such investment will contribute to GDP growth only at the time it is implemented, reduce the marginal product of capital, and lead to deadweight loss.

Investment-led growth by definition is a strategy where the government and/or the public corporate sector push the economy forward by investment, thereby raising the capital stock and inducing demand, and growth. However, if the rate of investment is too fast, or the scope of potential market expansion is limited, then government induced investment could become underutilized, and subsequently wasted due to depreciation. This includes genuine investment needs such as infrastructure which do not lead to the use of their services within a reasonable time frame upon completion.

More formally, this relationship can be described in growth accounting, based on a Cobb Douglas production function, as:

$\dot{y}=\left(\frac{F_{A}}{Y}\right) \dot{a}+\left(\frac{r K}{Y}\right)\left(\dot{k}_{u}+k_{w}\right)+\left(\frac{w L}{Y}\right) \dot{l}$

where $\mathrm{k}_{\mathrm{u}}$ and $\mathrm{k}_{\mathrm{w}}$ are respectively used and unused/excess capital stock. In fact, $\mathrm{k}_{\mathrm{u}}$ is equal to the growth rate of the usual capital stock, i.e., rate of change of $\mathrm{K}_{\mathrm{u}}=\sum(1-\delta)^{t} \mathrm{I}_{\mathrm{u}}^{\mathrm{t}}$ where $\delta$ is the rate of depreciation, and $\mathrm{k}_{\mathrm{w}}$ is simply the rate of change of $\mathrm{K}_{\mathrm{w}}$, which is equal to $\mathrm{I}_{\mathrm{w}}$ since this part of investment is not used as capital stock and is unproductive. In other words, (1) can be written as:

$\dot{y}=\left(\frac{F_{A}}{Y}\right) \dot{a}+\left(\frac{r K}{Y}\right)\left(\dot{k}_{u}+i_{w}\right)+\left(\frac{w L}{Y}\right) \dot{l}$

\section{B. Identifying Excessive Investment Empirically}

Conceptually, unused investment could be estimated by calculating excess capacity. While underutilized capacity arising from cyclical fluctuations can be estimated relatively easily, 
such estimation is more difficult in the case of unused/wasted investment. This is because unused investment will push up output such that the actual efficiency of the capital stock is overestimated.

An alternative way of showing the degree of potential waste in the use of the capital stock is to approach it from the expenditure side of GDP (Figure 1).

$\dot{y}=\left(\frac{C}{Y}\right) \dot{c}+\left(\frac{I_{u}}{Y}\right) \dot{i}_{u}+\left(\frac{I_{w}}{Y}\right) \dot{i}_{w}+\left(\frac{N X}{Y}\right) r \dot{x}$

where $i_{u}$ and $i_{w}$ are each growth rates of $I_{u}$ and $I_{w}$. Market determined investment that becomes part of Figure 1. Investment induced growth path the capital stock will contribute both to corporate and household income concurrently and in the future, and to consumption. Consumption, or expected consumption, in turn will be a key determinant of investment. However, in provinces where the local government accounts for a larger share of investment, the latter tends to initiate the causality, contributing to corporate income and then, to a lesser extent, to household income. Moreover, if investment is excessive, it will tend to contribute only to the concurrent period GDP.

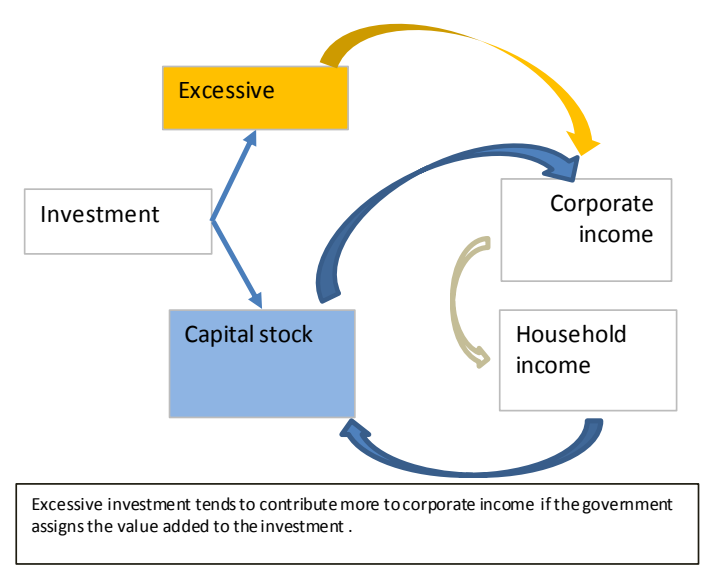

Thus, as a second best approach to estimating investment wastage, one could look at GDP excluding investment, $\mathrm{GDP}_{\mathrm{adj}, \mathrm{t}}=\mathrm{GDP}_{\mathrm{t}}-\mathrm{I}_{\mathrm{t}}$. This would measure the productivity of investment up to $\mathrm{t}-1$ and whatever spillover from $\mathrm{I}_{\mathrm{t}}$ on $\mathrm{GDP}_{\mathrm{t}}$. If the share of wasted investment, $\mathrm{I}_{\mathrm{w}}$ is persistently high, then the share of investment to GDP will tend to increase as excessive investment contributes to concurrent GDP growth but not to the underlying capital stock.

This approach obviously also has drawbacks, one of which is that persistently larger investment could keep GDP growth higher than that of $\mathrm{GDP}_{\text {adj }}$ even in the absence of unused investment. ${ }^{2}$ Nevertheless, it could be a useful proxy for identifying excessive investment.

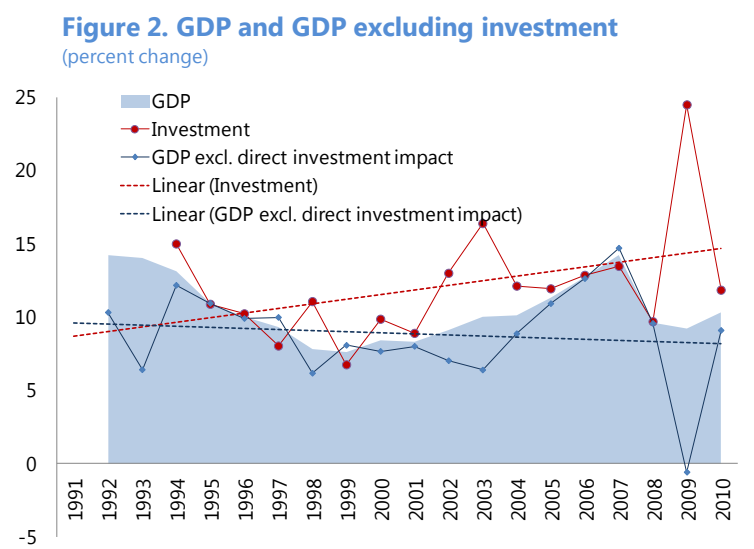

\footnotetext{
${ }^{2}$ Traditional measures of investment efficiency like ICORs also suffer from the same limitation.
} 
To the extent that investment growth in China has been trending upwards and GDP adj growth downwards over the last two decades, it suggests that investment efficiency has been declining, or put differently, the share of excessive investment has been increasing (Figure 2).

A review of individual provinces shows that GDP growth has been relying increasingly on contemporaneous investment with little evidence to suggest that the increment to the capital stock is contributing to future growth (Figures 3 and 4). This is more evident in inland (the Center and West of China) than in coastal provinces, especially in the last few years, with some $\mathrm{GDP}_{\text {adj }}$ in some inland provinces falling to as low as 10 percent. Indeed, two-thirds of the rise in China's investment-to-GDP ratio and all of the decline in China's private consumption to GDP ratio over the last ten years is attributable to inland provinces.
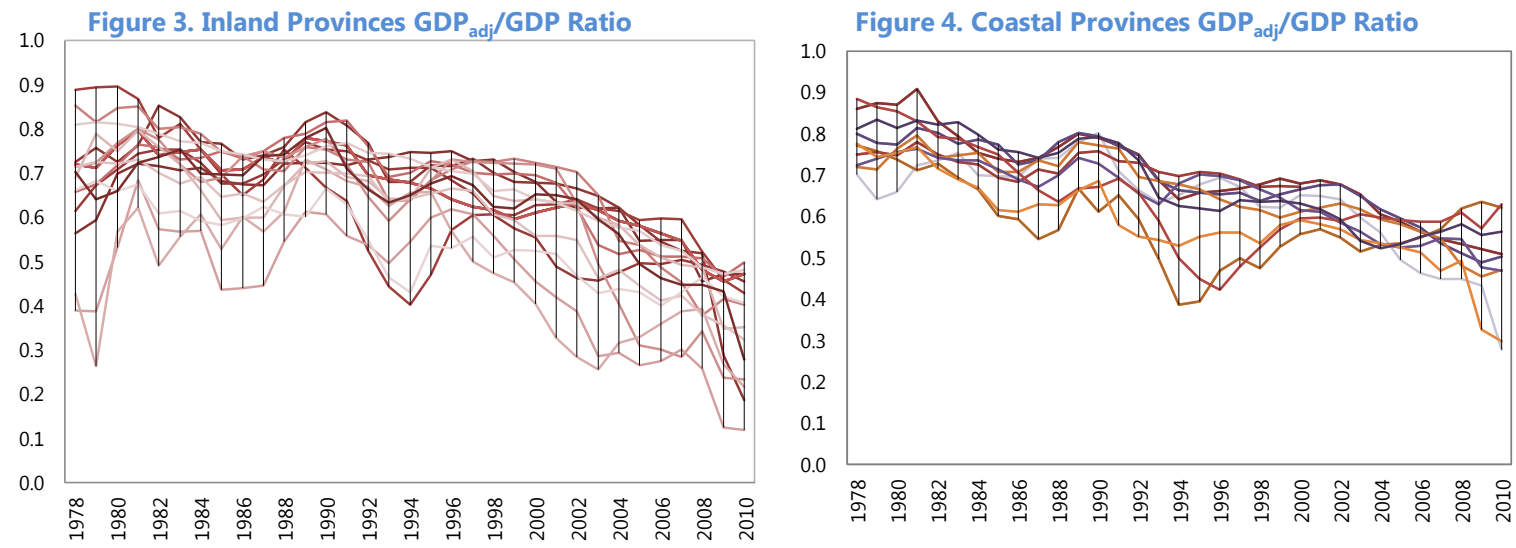

\section{EMPIRICAL TESTS}

The following testable implications arise from our conceptual framework:

Implication 1. If investment is excessive, we should find that consumption is not selfsustaining, but dependent on recent investment, i.e. investment should Granger-cause consumption and consumption should have little lasting power on its own. We would expect the transmission from investment to consumption to be through household income.

Implication 2. If investment is excessive, it should result in greater corporate profitability rather than boosting household income. This is because wasted investment would contribute to corporate income during the implementation period, and to a lesser extent to household income, the scope of which would depend on the share of labor costs. However, the normal channel whereby investment leads to higher capital stock, and then higher growth and income thereafter, will be much weaker.

We tested these using provincial-level data over the period 1978-2011 covering all of China's 22 provinces, 3 municipalities (all except Chongqing), and the 4 autonomous regions (all except Tibet). Provincial GDP and exports were deflated using provincial GDP deflators, 
and provincial consumption and investment by provincial CPI and FAI investment price indices, respectively. The base year was 2000 . We treated the following 10 jurisdictions as coastal, in line with standard definitions: Beijing, Hebei, Fujian, Guangdong, Hainan, Jiangsu, Shandong, Shanghai, Tianjin and Zhejiang. The rest were considered inland, with the exception of the North eastern provinces of Liaoning and Heilongjiang. All the variables were found to be I(1) using panel unit roots tests (Augmented-Dickey Fuller). As a result, our models are estimated in growth rates (log first-differences), to ensure stationarity.

\section{A. Testing Implication 1}

To assess the extent to which private consumption in China is reliant upon investment, we first conducted some basic Granger causality tests (Table 1). To establish causal direction, we began with Granger tests adapted to a panel framework (see, e.g., Hurlin (2008)). These tests assess whether there is any additional information in the lagged values of the explanatory variable relevant for predicting the current value of the

\begin{tabular}{|c|c|c|c|}
\hline & Lags & Wald (p-value) & Result \\
\hline Overall & 3 & 0.000 & Reject \\
\hline Pre-2000 & 3 & 0.000 & Reject \\
\hline Post-2000 & 3 & 0.001 & Reject \\
\hline Coast & 3 & 0.784 & Accept \\
\hline Pre-2000 & 3 & 0.001 & Reject \\
\hline Post- 2000 & 3 & 0.338 & Accept \\
\hline Non-coast & 3 & 0.001 & Reject \\
\hline Pre-2000 & 3 & 0.000 & Reject \\
\hline Post-2000 & 3 & 0.000 & Reject \\
\hline
\end{tabular}
dependent variable, conditional on its own lags. To determine the optimal number of lags in the estimation, we ran bivariate VARs and used the Akaike information criterion. Once this was determined, we estimated a dynamic panel model and used a Wald test to establish whether the values of the explanatory variables were significant. For our overall sample and most sub-sample splits, we found evidence in favor of the hypothesis that investment Granger-causes private consumption. ${ }^{3}$ The only exception is in the case of coastal provinces in the post-2000 period.

More formally, we assessed the economic significance of this relationship. Based on our conceptual framework, one way to gauge whether investment is excessive in provinces is to estimate to what extent household consumption is influenced by $\mathrm{GDP}_{\text {adj }}$ and investment. So for each province, we estimated:

\footnotetext{
${ }^{3}$ Tests were also conducted on whether private consumption "Granger causes" investment. No evidence of such reverse causality was detected, again with the exception of coastal provinces post- 2000 .
} 
Consumption $_{\mathrm{t}}=\mathrm{F}\left(\mathrm{GDP}_{\mathrm{adj}, \mathrm{t}-\mathrm{j}} ;\right.$ Investment $\left._{\mathrm{t}-\mathrm{j}}\right)$ where $\mathrm{j}=[0, \ldots]$

This will inform us of the nature of investment effectiveness in that province. In particular, the coefficient of $\mathrm{GDP}_{\text {adj }}$ should reflect to what extent past investment has contributed to the capital stock, i.e., $\mathrm{K}_{\mathrm{t}-1}$, and thus underlying growth. If this impact is small, investment in that province is likely to be excessive. On the other hand, the coefficient on the investment variables will capture the more direct and transitory impact. For private consumption to be self-sustaining and the economy to have the absorptive capacity to accommodate high levels of investment, we would expect a larger and more significant coefficient on $\mathrm{GDP}_{\text {adj. }}$. Conversely, if the coefficient on the investment variables dominates, it would be suggestive of absorptive constraints and waste such that investment only affects private consumption over the short period.

Our results are shown in Table 1. First, we estimated equation 1 using fixed effects (panel A). Then, to allow for potential endogeneity of the regressors, we estimated the same specification using GMM and lagged values as instruments (panel B). ${ }^{4}$ Finally, to allow for the possibility that GDP adj may be highly collinear with private consumption, we replace $\mathrm{GDP}_{\text {adj }}$ with the first lag of private consumption (panel C). All our models relate private consumption in province $i$ at time $t$ to investment and its lags, together with additional control variables (either $\mathrm{GDP}_{\text {adj }}$ and its lag or lagged private consumption). All the variables are expressed in real terms and estimation is in first-differenced logs (growth rates). Below, we focus mostly on the results with GMM and the lagged dependent variable shown in Panel $\mathrm{C}$ (as potentially the most robust of the three), but note that the results using the other two techniques are qualitatively similar:

\footnotetext{
${ }^{4}$ GMM will provide unbiased and consistent estimates provided the instruments are valid and there is no
} higher-order serial correlation in the residuals. Both conditions were assessed using standard tests. 
Table 2. Identifying Excessive Investment: Is Private Consumption Self-Sustaining? (1978-2011) 1/ 2 /

\begin{tabular}{|c|c|c|c|c|c|c|c|c|c|}
\hline & (1) & (2) & (3) & (4) & (5) & (6) & (7) & (8) & (9) \\
\hline & & & & & & \multicolumn{2}{|c|}{ Coast } & \multicolumn{2}{|c|}{ Inland } \\
\hline & Overall & Pre-2000 & Post-2000 & Coast & Inland & Pre-2000 & Post-2000 & Pre-2000 & Post-2000 \\
\hline Observations & 870 & 551 & 319 & 300 & 510 & 190 & 110 & 323 & 187 \\
\hline Number of regions & 29 & 29 & 29 & 10 & 17 & 10 & 10 & 17 & 17 \\
\hline & \multicolumn{9}{|c|}{ A. Fixed effects } \\
\hline GDPadj $_{\mathrm{t}}$ & $\begin{array}{c}0.169^{\star \star \star} \\
(0.02)\end{array}$ & $\begin{array}{c}0.384^{\star \star \star} \\
(0.04)\end{array}$ & $\begin{array}{l}0.047 \\
(0.04)\end{array}$ & $\begin{array}{c}0.271^{\star \star \star} \\
(0.05)\end{array}$ & $\begin{array}{c}0.119^{\star \star \star} \\
(0.03)\end{array}$ & $\begin{array}{c}0.390^{\star \star \star} \\
(0.06)\end{array}$ & $\begin{array}{c}-0.027 \\
(0.09)\end{array}$ & $\begin{array}{c}0.320^{\star \star \star} \\
(0.05)\end{array}$ & $\begin{array}{c}0.089^{*} \\
(0.05)\end{array}$ \\
\hline GDPadj $\mathrm{t}-1$ & $\begin{array}{l}0.026 \\
(0.02)\end{array}$ & $\begin{array}{c}-0.001 \\
(0.03)\end{array}$ & $\begin{array}{l}0.054 \\
(0.05)\end{array}$ & $\begin{array}{l}-0.070 \\
(0.05)\end{array}$ & $\begin{array}{c}0.078^{\star \star} \\
(0.03)\end{array}$ & $\begin{array}{c}0.126^{* *} \\
(0.06)\end{array}$ & $\begin{array}{l}0.081 \\
(0.10)\end{array}$ & $\begin{array}{c}0.136^{\star \star \star} \\
(0.05)\end{array}$ & $\begin{array}{l}0.014 \\
(0.06)\end{array}$ \\
\hline Investment $\mathrm{t}$ & $\begin{array}{c}0.156^{\star \star \star} \\
(0.02)\end{array}$ & $\begin{array}{c}0.181^{\star \star \star} \\
(0.02)\end{array}$ & $\begin{array}{c}0.118^{\star \star} \\
(0.06)\end{array}$ & $\begin{array}{c}0.190^{\star \star \star} \\
(0.03)\end{array}$ & $\begin{array}{c}0.130^{\star \star \star} \\
(0.02)\end{array}$ & $\begin{array}{c}0.209^{\star \star \star} \\
(0.03)\end{array}$ & $\begin{array}{c}-0.082 \\
(0.10)\end{array}$ & $\begin{array}{c}0.141^{\star \star \star} \\
(0.02)\end{array}$ & $\begin{array}{c}0.230^{\star \star} \\
(0.09)\end{array}$ \\
\hline Investment $t_{-1}$ & $\begin{array}{l}0.015 \\
(0.02)\end{array}$ & $\begin{array}{l}0.008 \\
(0.02)\end{array}$ & $\begin{array}{l}0.001 \\
(0.06)\end{array}$ & $\begin{array}{l}0.025 \\
(0.03)\end{array}$ & $\begin{array}{l}0.019 \\
(0.02)\end{array}$ & $\begin{array}{l}0.032 \\
(0.03)\end{array}$ & $\begin{array}{l}0.122 \\
(0.11)\end{array}$ & $\begin{array}{l}0.022 \\
(0.02)\end{array}$ & $\begin{array}{c}-0.106 \\
(0.09)\end{array}$ \\
\hline Investment $t_{t-2}$ & $\begin{array}{c}0.053^{\star \star \star} \\
(0.01)\end{array}$ & $\begin{array}{c}0.038^{\star \star \star} \\
(0.01)\end{array}$ & $\begin{array}{l}0.073 \\
(0.05)\end{array}$ & $\begin{array}{c}0.061^{\star *} \\
(0.03)\end{array}$ & $\begin{array}{c}0.048^{\star *} \\
(0.02)\end{array}$ & $\begin{array}{c}0.054^{*} \\
(0.03)\end{array}$ & $\begin{array}{l}0.135 \\
(0.09)\end{array}$ & $\begin{array}{l}0.022 \\
(0.02)\end{array}$ & $\begin{array}{l}0.070 \\
(0.07)\end{array}$ \\
\hline Investment $t_{t-3}$ & $\begin{array}{c}0.033^{\star \star} \\
(0.01)\end{array}$ & $\begin{array}{c}0.032^{\star \star} \\
(0.01)\end{array}$ & $\begin{array}{l}0.037 \\
(0.05)\end{array}$ & $\begin{array}{l}0.034 \\
(0.03)\end{array}$ & $\begin{array}{c}0.031^{*} \\
(0.02)\end{array}$ & $\begin{array}{l}0.037 \\
(0.03)\end{array}$ & $\begin{array}{l}0.107 \\
(0.09)\end{array}$ & $\begin{array}{l}0.024 \\
(0.02)\end{array}$ & $\begin{array}{l}-0.033 \\
(0.07)\end{array}$ \\
\hline Constant & $\begin{array}{c}0.036^{\star \star \star} \\
(0.01)\end{array}$ & $\begin{array}{c}0.017^{\star *} \\
(0.01)\end{array}$ & $\begin{array}{c}0.053^{\star \star \star} \\
(0.02)\end{array}$ & $\begin{array}{c}0.038^{\star \star \star} \\
(0.01)\end{array}$ & $\begin{array}{c}0.036^{\star \star \star} \\
(0.01)\end{array}$ & $\begin{array}{c}0.022^{*} \\
(0.01)\end{array}$ & $\begin{array}{c}0.066^{\star \star} \\
(0.03)\end{array}$ & $\begin{array}{c}0.013^{*} \\
(0.01)\end{array}$ & $\begin{array}{c}0.056^{\star \star} \\
(0.03)\end{array}$ \\
\hline R-squared & 0.127 & 0.258 & 0.030 & 0.221 & 0.101 & 0.355 & 0.098 & 0.220 & 0.056 \\
\hline & \multicolumn{9}{|c|}{ B. GMM 3/ } \\
\hline GDPadj $_{\mathrm{t}}$ & $\begin{array}{c}0.215^{\star \star \star} \\
(0.07)\end{array}$ & $\begin{array}{c}0.398^{\star \star \star} \\
(0.14)\end{array}$ & $\begin{array}{l}-0.010 \\
(0.09)\end{array}$ & $\begin{array}{c}0.451^{\star \star} \\
(0.21)\end{array}$ & $\begin{array}{c}0.251^{\star \star \star} \\
(0.09)\end{array}$ & $\begin{array}{c}0.686^{*} \\
(0.35)\end{array}$ & $\begin{array}{c}0.119 * * \\
(0.06)\end{array}$ & $\begin{array}{c}0.472^{\star \star \star} \\
(0.15)\end{array}$ & $\begin{array}{l}0.215 \\
(0.15)\end{array}$ \\
\hline GDPadj $_{\mathrm{t}-1}$ & $\begin{array}{l}0.099 \\
(0.06)\end{array}$ & $\begin{array}{c}0.253^{\star \star} \\
(0.12)\end{array}$ & $\begin{array}{l}0.232^{*} \\
(0.13)\end{array}$ & $\begin{array}{l}0.093 \\
(0.17)\end{array}$ & $\begin{array}{l}0.160^{*} \\
(0.09)\end{array}$ & $\begin{array}{c}-0.349 \\
(0.37)\end{array}$ & $\begin{array}{c}0.289^{\star \star} \\
(0.09)\end{array}$ & $\begin{array}{c}-0.065 \\
(0.12)\end{array}$ & $\begin{array}{l}-0.067 \\
(0.21)\end{array}$ \\
\hline Investment ${ }_{t}$ & $\begin{array}{c}0.219^{\star \star \star} \\
(0.04)\end{array}$ & $\begin{array}{c}0.310^{\star \star \star} \\
(0.04)\end{array}$ & $\begin{array}{l}0.067 \\
(0.20)\end{array}$ & $\begin{array}{l}0.208^{*} \\
(0.12)\end{array}$ & $\begin{array}{c}0.230^{\star \star \star} \\
(0.04)\end{array}$ & $\begin{array}{c}0.189^{\star \star \star} \\
(0.04)\end{array}$ & $\begin{array}{l}0.080 \\
(0.15)\end{array}$ & $\begin{array}{c}0.258^{\star \star \star} \\
(0.03)\end{array}$ & $\begin{array}{c}0.492^{\star *} \\
(0.25)\end{array}$ \\
\hline Investment $t_{-1}$ & $\begin{array}{c}0.061^{*} \\
(0.04)\end{array}$ & $\begin{array}{c}-0.002 \\
(0.03)\end{array}$ & $\begin{array}{l}0.228 \\
(0.24)\end{array}$ & $\begin{array}{l}0.020 \\
(0.12)\end{array}$ & $\begin{array}{l}0.074 \\
(0.06)\end{array}$ & $\begin{array}{l}0.067 \\
(0.07)\end{array}$ & $\begin{array}{c}-0.015 \\
(0.21)\end{array}$ & $\begin{array}{l}0.000 \\
(0.04)\end{array}$ & $\begin{array}{c}-0.489 \\
(0.31)\end{array}$ \\
\hline Investment $t_{t-2}$ & $\begin{array}{c}0.076^{\star \star \star} \\
(0.02)\end{array}$ & $\begin{array}{l}0.061 \\
(0.04)\end{array}$ & $\begin{array}{c}0.289^{\star \star \star} \\
(0.11)\end{array}$ & $\begin{array}{l}0.072 \\
(0.14)\end{array}$ & $\begin{array}{c}-0.011 \\
(0.09)\end{array}$ & $\begin{array}{l}0.026 \\
(0.07)\end{array}$ & $\begin{array}{l}0.102 \\
(0.13)\end{array}$ & $\begin{array}{l}0.020 \\
(0.05)\end{array}$ & $\begin{array}{c}0.241^{*} \\
(0.13)\end{array}$ \\
\hline Investment $t_{-3}$ & $\begin{array}{c}0.085^{\star \star} \\
(0.04)\end{array}$ & $\begin{array}{c}0.192^{\star \star \star} \\
(0.05)\end{array}$ & $\begin{array}{c}-0.086 \\
(0.10)\end{array}$ & $\begin{array}{l}0.047 \\
(0.14)\end{array}$ & $\begin{array}{c}0.092^{\star \star \star} \\
(0.04)\end{array}$ & $\begin{array}{l}0.142^{*} \\
(0.08)\end{array}$ & $\begin{array}{c}-0.102 \\
(0.90)\end{array}$ & $\begin{array}{c}0.084^{\star \star} \\
(0.04)\end{array}$ & $\begin{array}{l}0.238 \\
(0.17)\end{array}$ \\
\hline $\begin{array}{l}\text { m2 test (p-value) } 4 / \\
\text { Hansen test (p-value) } 5 \text { / }\end{array}$ & $\begin{array}{l}0.925 \\
1.000\end{array}$ & $\begin{array}{l}0.721 \\
1.000\end{array}$ & $\begin{array}{l}0.246 \\
1.000\end{array}$ & $\begin{array}{l}0.529 \\
1.000\end{array}$ & $\begin{array}{l}0.217 \\
1.000\end{array}$ & $\begin{array}{l}0.375 \\
1.000\end{array}$ & $\begin{array}{l}0.486 \\
1.000\end{array}$ & $\begin{array}{l}0.357 \\
1.000\end{array}$ & $\begin{array}{l}0.239 \\
1.000\end{array}$ \\
\hline & \multicolumn{9}{|c|}{ C. GMM with lagged dependent variable 3/ } \\
\hline Private consumption $\mathrm{t}-1$ & $\begin{array}{c}0.704^{\star \star \star} \\
(0.08)\end{array}$ & $\begin{array}{c}0.529 * \star \star \\
(0.07)\end{array}$ & $\begin{array}{l}0.341 \\
(0.27)\end{array}$ & $\begin{array}{c}0.838^{\star \star \star} \\
(0.12)\end{array}$ & $\begin{array}{c}0.731^{\star \star \star} \\
(0.09)\end{array}$ & $\begin{array}{c}0.598^{\star *} \\
(0.23)\end{array}$ & $\begin{array}{c}0.727^{\star \star \star} \\
(0.26)\end{array}$ & $\begin{array}{c}0.720 \text { *** } \\
(0.08)\end{array}$ & $\begin{array}{l}0.361 \\
(0.23)\end{array}$ \\
\hline Investment $t_{t}$ & $\begin{array}{c}0.178^{\star \star \star} \\
(0.03)\end{array}$ & $\begin{array}{c}0.224^{\star \star \star} \\
(0.03)\end{array}$ & $\begin{array}{c}0.221^{\star \star} \\
(0.10)\end{array}$ & $\begin{array}{l}0.141 \\
(0.19)\end{array}$ & $\begin{array}{c}0.133^{\star *} \\
(0.06)\end{array}$ & $\begin{array}{c}0.266^{\star \star \star} \\
(0.10)\end{array}$ & $\begin{array}{l}0.075 \\
(0.11)\end{array}$ & $\begin{array}{c}0.169^{\star \star \star} \\
(0.04)\end{array}$ & $\begin{array}{l}0.229^{\star} \\
(0.13)\end{array}$ \\
\hline Investment $\mathrm{t}_{-1}$ & $\begin{array}{c}-0.054 \\
(0.05)\end{array}$ & $\begin{array}{l}-0.031 \\
(0.05)\end{array}$ & $\begin{array}{l}-0.223 \\
(0.15)\end{array}$ & $\begin{array}{l}-0.067 \\
(0.34)\end{array}$ & $\begin{array}{r}-0.060 \\
(0.08)\end{array}$ & $\begin{array}{c}-0.098 \\
(0.12)\end{array}$ & $\begin{array}{c}-0.012 \\
(0.22)\end{array}$ & $\begin{array}{l}-0.061 \\
(0.06)\end{array}$ & $\begin{array}{l}-0.246 \\
(0.15)\end{array}$ \\
\hline Investment $t_{-2}$ & $\begin{array}{l}0.076^{*} \\
(0.04)\end{array}$ & $\begin{array}{l}0.062 \\
(0.04)\end{array}$ & $\begin{array}{c}0.382^{\star \star} \\
(0.15)\end{array}$ & $\begin{array}{l}0.134 \\
(0.57)\end{array}$ & $\begin{array}{c}0.117^{\star *} \\
(0.05)\end{array}$ & $\begin{array}{l}0.071 \\
(0.06)\end{array}$ & $\begin{array}{l}0.278 \\
(0.19)\end{array}$ & $\begin{array}{l}0.066 \\
(0.05)\end{array}$ & $\begin{array}{c}0.315^{\star *} \\
(0.14)\end{array}$ \\
\hline Investment $t_{-3}$ & $\begin{array}{l}-0.007 \\
(0.03)\end{array}$ & $\begin{array}{c}0.057^{\star *} \\
(0.03)\end{array}$ & $\begin{array}{l}0.033 \\
(0.18)\end{array}$ & $\begin{array}{c}-0.074 \\
(0.49)\end{array}$ & $\begin{array}{l}-0.028 \\
(0.03)\end{array}$ & $\begin{array}{l}0.080 \\
(0.10)\end{array}$ & $\begin{array}{l}-0.118 \\
(0.12)\end{array}$ & $\begin{array}{l}0.008 \\
(0.04)\end{array}$ & $\begin{array}{l}0.052 \\
(0.17)\end{array}$ \\
\hline m2 test (p-value) 4/ & 0.194 & 0.166 & 0.576 & 0.653 & 0.416 & 0.813 & 0.721 & 0.178 & 0.856 \\
\hline Hansen test ( $p$-value) 5 / & 1.000 & 1.000 & 0.936 & 1.000 & 1.000 & 1.000 & 1.000 & 1.000 & 1.000 \\
\hline
\end{tabular}

CInternational Monetary Fund. Not for Redistribution 
For our overall sample, private consumption is significantly dependent on investment. As shown in column 1, the instant effect is largest, but investment up to 3 years prior also has an impact. Overall, a 10 percent increase in investment increases private consumption by around 2 percent in the first year and up to 3 percent over time. Private consumption is also persistent, suggesting some self-sustenance, with around 70 percent of its growth in the current year explained by that in the previous year.

Since 2000, however, consumption seems to have become more dependent on investment. Columns 2 and 3 suggest that while the immediate impact of investment is similar in the preand post-2000 periods, the overall impact has become stronger in the latter period, with a 10 percent increase in investment leading to an increase of up to 6 percent in private consumption over three years. Over the same period, there is also less evidence of selfsustaining private consumption, with both the lagged dependent variable and lagged GDP adj either insignificant or having a much smaller impact on private consumption growth. This finding is suggestive of elevated investment beginning to strain absorptive capacity in the recent period, with investment leading to a direct impact that private consumption has become more sensitive to, but no longer eliciting a strong and sustained indirect response.

Taking the entire time-period of our sample, there appears to be some self-sustenance of private consumption in both coastal and inland regions but the latter are more dependent on direct support from investment (columns 4 and 5) In the coastal regions, there is no direct dependence of private consumption on investment, while for the inland regions a 10 percent increase in investment leads to a 2.5-3 percent increase in private consumption over time (as found in the overall sample).

However, our sub-sample analysis uncovers important divergences between coastal and noncoastal areas. While the behavior of private consumption and its relationship with our control variables was broadly similar across coastal and inland provinces before 2000, it has diverged significantly since then.

On the one hand, for coastal areas, private consumption has become more self-sustaining and less reliant on investment over time (columns 6 and 7). While the effect of investment on private consumption used to be large and tangible pre-2000, it is now insignificant. In that sense, private consumption has become more self-sustaining, as evidenced by a larger coefficient on lagged private consumption than in the earlier period.

In sharp contrast, for non-coastal areas, the dependence of private consumption on investment has grown (columns 8 and 9, and Figure 5). In particular, the direct impact of

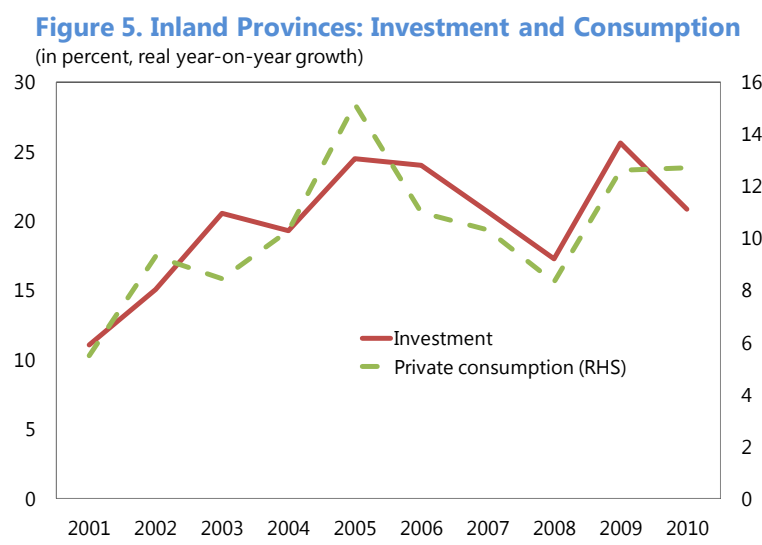


investment on private consumption growth in the inland provinces has magnified, with the effect of a 10 percent increase in investment on private consumption growth rising from around 1.5 percent before 2000 to almost 6 percent in the last decade. At the same time, private consumption also seems to have become much less self-sustaining, with little underlying momentum (insignificant coefficient on lagged private consumption) and a much weaker (if not insignificant) relationship with $\mathrm{GDP}_{\text {adj. }}$. This result cautions that consumption has become more dependent on continuous investment in recent years in the inland areas of China but that the impact of this investment is short-lived and does not spill over to underlying GDP, suggesting increasingly diminishing absorptive capacity and much weaker feed-through effects from capital formation in non-coastal areas over time.

A potential concern regarding our specification is that it is reduced form and may therefore be subject to omitted variables bias. As a robustness check, therefore, we also used a more standard structural consumption function, by relating the growth in private consumption to its own lag, and growth in real public consumption, household income, bank credit, the share of employment in services and the old-age dependency ratio (Table 3). Most of the variables had the expected signs (column 1), although the following were not found to be significant: public consumption (possibly reflecting its relatively small size in China), bank credit (likely due to the limited scale of consumer and SME finance), and employment in services (whose

Table 3. China: Standard Consumption Function (1997-2010) 1/

\begin{tabular}{|c|c|c|c|c|}
\hline & $(1)$ & $(2)$ & (3) & (4) \\
\hline Private consumption ${ }_{t-1}$ & $\begin{array}{c}0.710^{\star \star \star} \\
(0.16)\end{array}$ & $\begin{array}{c}0.691^{\star \star \star} \\
(0.10)\end{array}$ & $\begin{array}{c}0.586^{\star \star \star} \\
(0.17)\end{array}$ & $\begin{array}{c}0.773^{\star \star \star} \\
(0.12)\end{array}$ \\
\hline Household Income $_{t}$ & $\begin{array}{c}0.426^{\star \star \star} \\
(0.15)\end{array}$ & $\begin{array}{c}0.385^{\star \star \star} \\
(0.11)\end{array}$ & $\begin{array}{c}0.359^{\star \star \star} \\
(0.12)\end{array}$ & \\
\hline Public consumption $_{\mathrm{t}}$ & $\begin{array}{l}-0.042 \\
(0.07)\end{array}$ & & & \\
\hline Bank credit ${ }_{t}$ & $\begin{array}{l}-0.036 \\
(0.05)\end{array}$ & & & \\
\hline Share of employment in services $t$ & $\begin{array}{l}0.143 \\
(0.22)\end{array}$ & & & \\
\hline Old-age dependency ratio ${ }_{t}$ & $\begin{array}{c}0.095^{*} \\
(0.06)\end{array}$ & $\begin{array}{c}0.108^{\star *} \\
(0.04)\end{array}$ & $\begin{array}{c}0.082^{\star *} \\
(0.04)\end{array}$ & $\begin{array}{l}0.077^{*} \\
(0.04)\end{array}$ \\
\hline Investment $\mathrm{t}_{\mathrm{t}}$ & & & $\begin{array}{l}0.073 \\
(0.08)\end{array}$ & $\begin{array}{c}0.139 \star \star \\
(0.06)\end{array}$ \\
\hline $\mathrm{m} 2$ test ( $p$-value) & 0.514 & 0.992 & 0.914 & 0.354 \\
\hline Hansen test ( $p$-value) & 0.988 & 0.992 & 0.989 & 0.990 \\
\hline Observations & 356 & 363 & 363 & 377 \\
\hline Number of regions & 29 & 29 & 29 & 29 \\
\hline
\end{tabular}

1/ Estimation in log first-differences and dependent variable is private consumption. See notes to Table 2. 
effect seems to be directly captured in household income). When we add investment to this specification, we found it to be insignificant (column 3 ). However, it was highly significant when we excluded household income from the regression (column 4). This is not surprising and is consistent with the implication of our framework that the effects of investment on private consumption are likely to be transmitted through boosting household incomes.

Visually, the main thrust of our results is clear in the chart below showing $\mathrm{GDP}_{\text {adj }}$ in both groups of provinces as share to GDP (Figure 6). While the ratio of both groups moved broadly in tandem, sliding gradually downwards, there is a clear break taking place beginning in early 2000s. For non-Eastern provinces, it fell sharply during most of 2000s, reaching 0.4 by 2010. In other words, the weighted average investment to GDP ratio reached 60 percent, holding up economic growth in each period without much impact on future

Figure 6 GDP Excluding Investment as a Share of GDP By Region

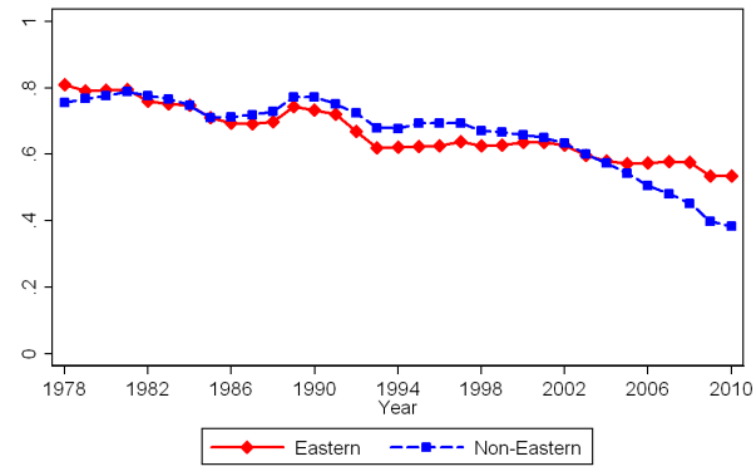
$\mathrm{GDP}_{\text {adj. }}$. A continuation of this trend will likely lead to large wastage of resources at a time when they are beginning to become increasingly costly to raise, as discussed in section $\mathrm{V}$.

\section{B. Testing Implication 2}

Our results suggest that, on average, investment in coastal areas elicits more of a sustained consumption response than that in China's inland provinces. In that sense, we find less evidence of that the average investment in coastal regions is excessive. To better understand why this may be the case, we carried out two additional exercises that also allowed us to test the second implication of our framework.

First, building on the result in Table 3 that investment affects private consumption through incomes, we took a closer look at the relationship between these two variables (Table 4). In a simple specification including the lagged dependent variable, we found that investment is positively associated with household income and that this relationship is stronger in coastal provinces compared to inland ones (columns 1 to

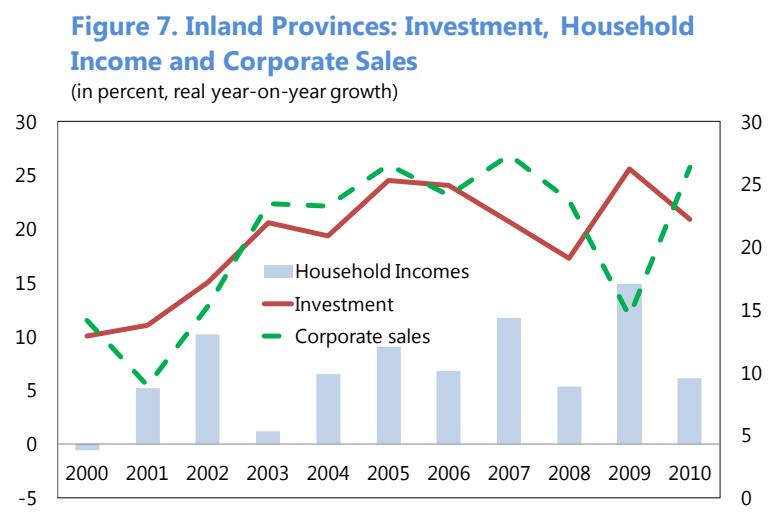
3). This is consistent with the view that there is a greater spillover from investment to household incomes in China's coastal provinces. Conversely, it appears that corporates benefit relatively more from investment in China's inland, at least in the short run, as reflected in a more significant association between 
current investment and corporate profitability in these regions (columns 4 to 6 , and Figure 7).

Table 4. China: Investment, Household Income and Corporate Profits $1 /$

\begin{tabular}{|c|c|c|c|c|c|c|}
\hline \multirow{3}{*}{ DEPENDENT VARIABLE } & (1) & (2) & (3) & (4) & (5) & (6) \\
\hline & \multicolumn{3}{|c|}{ HOUSEHOLD INCOME } & \multicolumn{3}{|c|}{ CORPORATE PROFITS } \\
\hline & Overall & Coast & Inland & Overall & Coast & Inland \\
\hline Household Income $t-1$ & $\begin{array}{c}0.709 * * \star \\
(0.04)\end{array}$ & $\begin{array}{c}0.610^{\star \star \star} \\
(0.12)\end{array}$ & $\begin{array}{c}0.848^{* * *} \\
(0.07)\end{array}$ & & & \\
\hline Corporate profits $\mathrm{t}-1$ & & & & $\begin{array}{c}0.815^{\star \star \star} \\
(0.04)\end{array}$ & $\begin{array}{c}0.869 * \star \star \\
(0.18)\end{array}$ & $\begin{array}{c}0.822^{\star \star \star} \\
(0.04)\end{array}$ \\
\hline Investment $t_{t}$ & $\begin{array}{c}0.173^{\star \star *} \\
(0.02)\end{array}$ & $\begin{array}{c}0.262^{\star * \star} \\
(0.08)\end{array}$ & $\begin{array}{l}0.080^{*} \\
(0.05)\end{array}$ & $\begin{array}{c}0.219 * \star \star \\
(0.04)\end{array}$ & $\begin{array}{l}0.165 \\
(0.18)\end{array}$ & $\begin{array}{c}0.210^{\star \star \star *} \\
(0.03)\end{array}$ \\
\hline m2 test ( $p$-value) & 0.088 & 0.152 & 0.196 & 0.213 & 0.433 & 0.236 \\
\hline Hansen test ( $p$-value) & 1.000 & 1.000 & 1.000 & 1.000 & 1.000 & 1.000 \\
\hline Observations & 813 & 270 & 486 & 522 & 180 & 306 \\
\hline Number of regions & 29 & 10 & 17 & 29 & 10 & 17 \\
\hline Time period & & $1978-2010$ & & & 1991-2010 & \\
\hline
\end{tabular}

$1 /$ Estimation in log first-differences and all variables are real. See notes to Table 2.

Second, to investigate what may account for differences in the traction between investment and household income among China's coast and inland, we also examined the importance of the sectoral allocation of capital. For China overall, as well as for both rural and urban areas, we detected a greater boost from investment in agriculture and services than for investment in manufacturing and real estate (Table 5). This is not surprising since agriculture and services tend to be more labor-intensive. These results suggest that some reorientation of investment

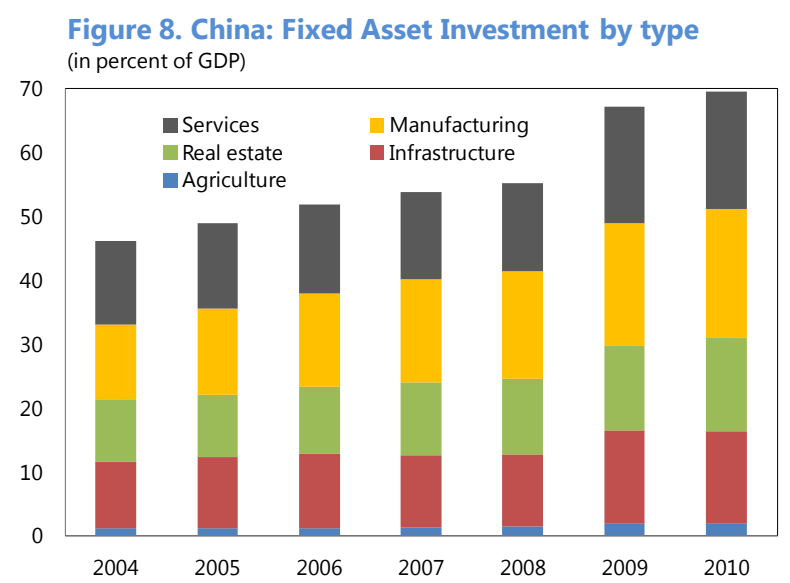
toward these sectors could help limit declines in consumption as overall investment is reduced, particularly in inland provinces. Interestingly, while these two sectors account for around 60 percent of China's GDP combined, they have only been responsible for one quarter of the rise in fixed asset investment observed since 2004 (Figure 8). This suggests considerable scope for investment to be re-allocated in their favor. 
Table 5. China: What Kind of Investment Boosts Household Incomes? (2004-10) 1/

\begin{tabular}{|c|c|c|c|c|c|c|}
\hline & $(1)$ & $(2)$ & (3) & (4) & (5) & (6) \\
\hline & \multicolumn{2}{|c|}{ Overall } & \multicolumn{2}{|c|}{ Rural } & \multicolumn{2}{|c|}{ Urban } \\
\hline Household Income $t-1$ & $\begin{array}{c}0.691^{\star \star \star} \\
(0.09)\end{array}$ & $\begin{array}{c}0.682^{\star \star \star} \\
(0.11)\end{array}$ & $\begin{array}{c}0.701^{\text {** }} \\
(0.12)\end{array}$ & $\begin{array}{c}0.697^{\star \star *} \\
(0.11)\end{array}$ & $\begin{array}{c}0.668^{\star \star \star} \\
(0.09)\end{array}$ & $\begin{array}{c}0.670^{\star \star \star *} \\
(0.09)\end{array}$ \\
\hline FAI in agriculture $t$ & $\begin{array}{l}0.141^{*} \\
(0.07)\end{array}$ & $\begin{array}{l}0.127^{*} \\
(0.07)\end{array}$ & $\begin{array}{c}0.059^{\star *} \\
(0.02)\end{array}$ & $\begin{array}{c}0.063^{\star \star} \\
(0.03)\end{array}$ & $\begin{array}{c}0.056^{\star \star \star} \\
(0.02)\end{array}$ & $\begin{array}{c}0.049^{* \star *} \\
(0.02)\end{array}$ \\
\hline FAI in manufacturing $t$ & $\begin{array}{l}0.065 \\
(0.08)\end{array}$ & $\begin{array}{l}0.090 \\
(0.14)\end{array}$ & $\begin{array}{l}-0.007 \\
(0.03)\end{array}$ & $\begin{array}{l}-0.005 \\
(0.03)\end{array}$ & $\begin{array}{l}-0.006 \\
(0.03)\end{array}$ & $\begin{array}{l}0.016 \\
(0.04)\end{array}$ \\
\hline FAI in services $t$ & $\begin{array}{c}0.307^{\star \star *} \\
(0.09)\end{array}$ & $\begin{array}{c}0.407^{\star *} \\
(0.18)\end{array}$ & $\begin{array}{l}0.077^{*} \\
(0.04)\end{array}$ & $\begin{array}{l}0.082 \\
(0.06)\end{array}$ & $\begin{array}{l}0.076^{*} \\
(0.04)\end{array}$ & $\begin{array}{c}0.138^{\star *} \\
(0.06)\end{array}$ \\
\hline FAI in real estate ${ }_{t}$ & & $\begin{array}{c}-0.112 \\
(0.18)\end{array}$ & & $\begin{array}{l}-0.009 \\
(0.05)\end{array}$ & & $\begin{array}{c}-0.072 \\
(0.06)\end{array}$ \\
\hline $\begin{array}{l}m 2 \text { test ( } p \text {-value) } \\
\text { Hansen test ( } p \text {-value) }\end{array}$ & $\begin{array}{l}0.389 \\
0.609\end{array}$ & $\begin{array}{l}0.413 \\
0.547\end{array}$ & $\begin{array}{l}0.468 \\
0.578\end{array}$ & $\begin{array}{l}0.416 \\
0.540\end{array}$ & $\begin{array}{l}0.127 \\
0.989\end{array}$ & $\begin{array}{l}0.104 \\
0.986\end{array}$ \\
\hline $\begin{array}{l}\text { Observations } \\
\text { Number of regions }\end{array}$ & $\begin{array}{c}162 \\
29\end{array}$ & $\begin{array}{c}162 \\
29\end{array}$ & $\begin{array}{c}174 \\
29\end{array}$ & $\begin{array}{c}174 \\
29\end{array}$ & $\begin{array}{c}174 \\
29\end{array}$ & $\begin{array}{c}174 \\
29\end{array}$ \\
\hline
\end{tabular}

$1 /$ Estimation in log first-differences. All variables are real and dependent variable is household income. See notes to Table 2.

\section{What About the AbILITY to FinAnCe ExCESSive InVESTMENT?}

A remarkable achievement not fully understood has been China's unprecedented ability to amass financing for high levels of investment during the last 30 years. Obviously the most important form of the financing was provided by high national savings. More generally, it should probably be attributed, among other things, to China's governance structure that provided a framework of stability and, to some extent, planned resource allocation including through cross-subsidization. More readily identifiable resources for investment have been the large stock of publicly owned land, cheap input costs (a different form of saving), abundant hard working labor, and ample liquidity (the direct counterpart of savings).

Thirty years ago, China's initial conditions were characterized by a system featuring a massively dislocated labor force, large quantities of publicly owned land, an underdeveloped financial system. All three provided the needed resources for rapid growth once the right governance structure ensured their proper use. Today, however, these resources are approaching their respective limits, such that further access to them will become increasingly costly. Coupled with some evidence of excessive investment, particularly at the provincial level, China may run out of its valuable resources before it can fully transform to a consumption-led growth model. We briefly review these three financing sources below and assess their sustainability. We end the section with an assessment of the extent to which China's relatively sound fiscal position and large international reserves could provide a 
buffer.

\section{A. Land Resources}

An important source of funding for investment, especially for provincial governments, was proceeds from land sales. By purchasing arable land cheaply from farmers and reclaiming waste or idle land, and selling them to developers, local governments were able to raise part of their funding for investment (and other spending). One formula applied for pricing of arable land was 10 times the annual yield of the land, which was seen as too low.

As the urbanization process accelerated, arable land hit the minimum limit set by the State Council for food security purposes in the late 2000s. In fact, in the last couple of years, there has been no net conversion of arable land into construction (Figure 9). Instead, local governments have been reclaiming land further away from urban areas and converting them into farm land - thereby ensuring that the floor on arable land is upheld—while purchasing

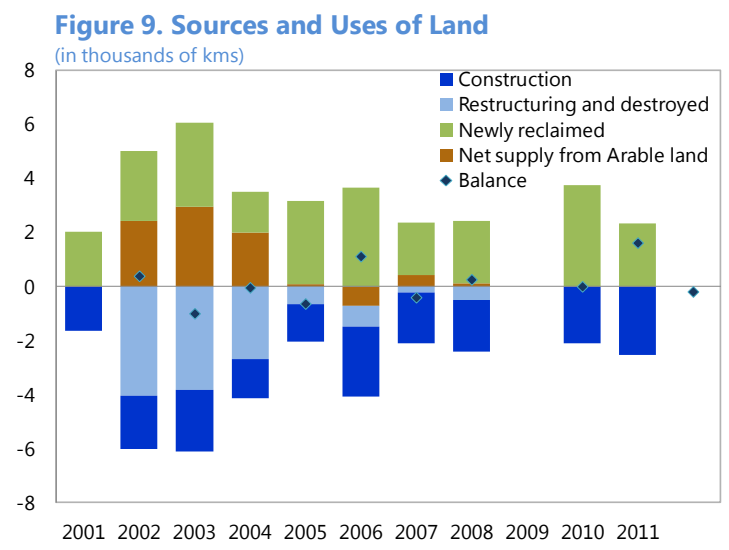
arable land closer to urban areas for development.

This model of financing is becoming increasingly more difficult as the government is now determined to ensure fair value on the purchased arable land. For example, the State Council passed a draft amendment of the Land Management Law that requires local governments to raise the purchasing value by ten-fold, sending a signal that future land procurements will not be cheap.

Moreover, land prices have been one of the key driving forces behind property price increases as local governments have tried to maximize revenue through their monopoly on land supply (Figure 10). In fact, local governments have faced tension for some time between the need to raise more revenue and keeping property prices low. With greater emphasis on containing growth of property prices to ensure affordability, they are constrained to do so. Thus, going forward, local governments' revenue is likely to

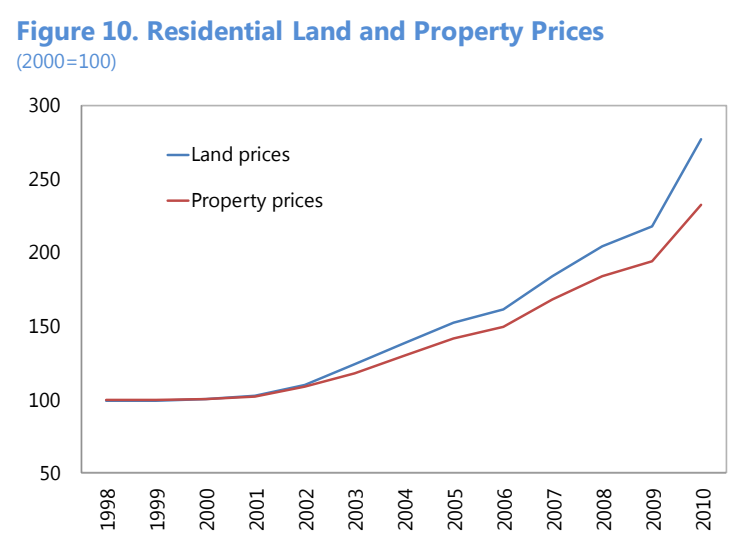
be squeezed from lower sales value to developers and higher procurement cost from farmers. According to some reports (China Daily, Jan 7, 2013), local government revenue from land 
sales reached RMB2.9 trillion in 2011, but fell to RMB2.35 trillion in the first 11 months of 2012 due to slow real estate market. At the same time, the cost of land acquisition rose to RMB1.69 trillion, amounting to 72 percent of land sales revenue.

\section{B. Abundant Labor}

Labor costs have been running below productivity increases in China for most of the last 30 years. This was partly facilitated by fast increases in the capital stock that was possible as the share of labor income was low, allowing corporates to invest more (Figure 11).

However, labor productivity relative to wage increases as measured by unit labor cost has moved into positive territory (authors' own calculation) since the late 2000s (Figure 12). This may be related to faster wage increases (or lower capital efficiency) which in turn can be explained by a tightening labor market. The relatively strong wage increases during 2012 when corporate profits were shrinking suggest that unit labor costs can reasonably be expected to stay positive in the future.

Relatedly, China's rising working population has been an important factor for ample financing. However, as some recent work illustrates, demography-induced savings are likely to have peaked already and will decline in the period ahead (Lee et al. (2013)).

\section{Bank Financing}

Liquidity has also been very important in facilitating investment in China. Starting from a very low base relative to various measures of the economy, including GDP and the capital stock, faster expansion of liquidity mainly in the form of bank financing has provided adequate funding for economic activity (Figure 13). In fact, when measured against the underlying productive capacity of the economy (as defined in Lee and Han (2012)), liquidity was less than half of the

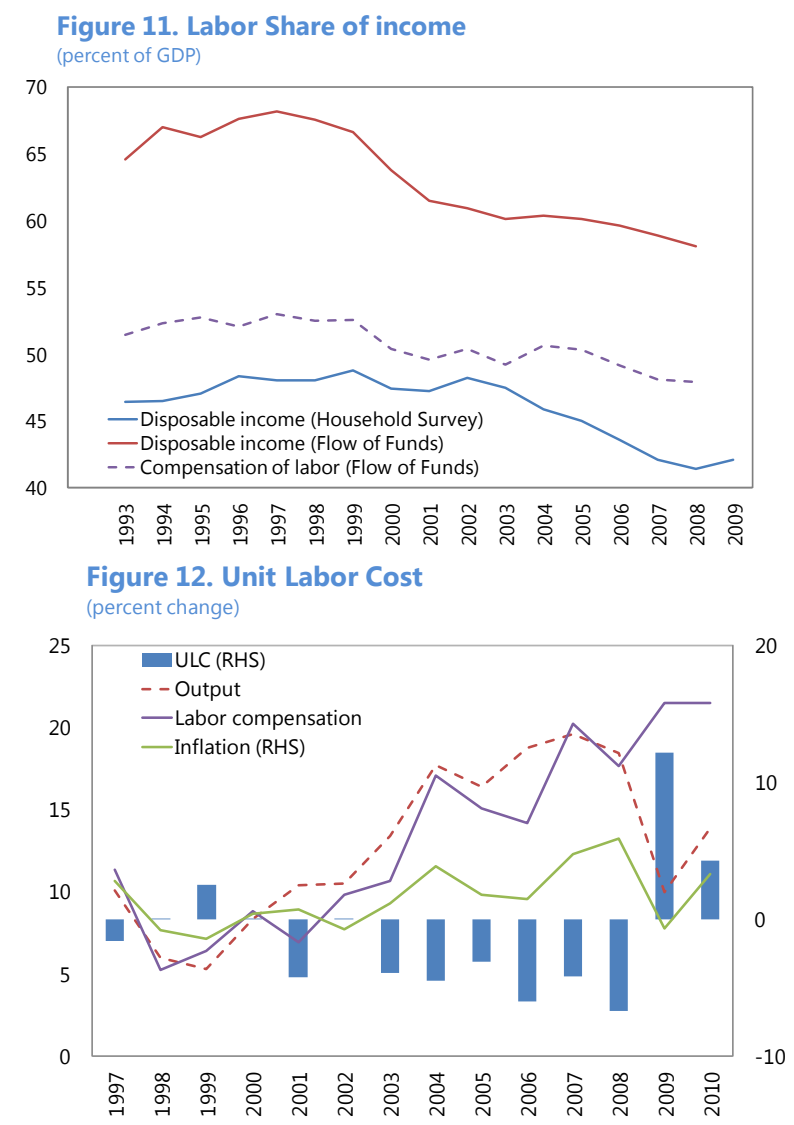


monetized value of capacity. This provided adequate space for liquidity to grow without exerting pressures on asset prices.

By the late 2000s, however, liquidity had surged well above the productive capacity immediately translating into asset price spikes; once in 2007 and in 2009-10 following the stimulus package (Figure 14). During the first episode, the overshooting of liquidity led to a stock market bubble that
Figure 14. Liquidity and Asset Prices

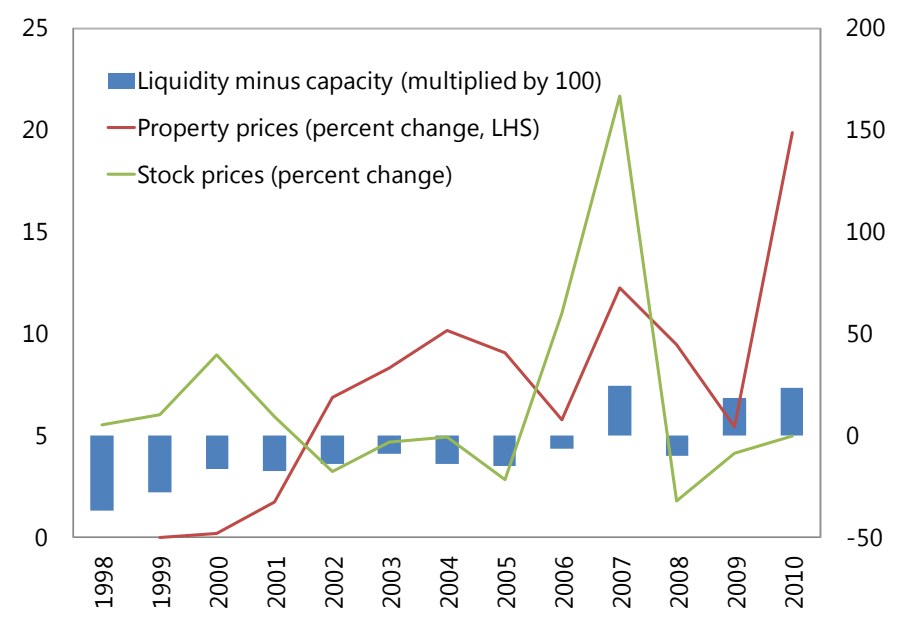
subsequently burst; the second expansion led to a rapid increase in property prices, as investors lost appetite for equities after the first episode. Thus, China no longer has the spare room it used to have to stimulate the economy through monetary expansion without creating pressures for asset bubbles. Now it will have to rely on efficiency gains in financial resource allocation.

\section{Government Resources}

With increasingly inefficient investment at the provincial levels, especially in nonEastern provinces, and tighter financing conditions, there is an urgent need for local governments to start to curtail investment. As they do so, investment decisions will have to pay attention to projects that will generate a greater and more lasting private sector response within a reasonable timeframe. This will take time, which the local governments do not have. Anecdotal evidence suggests that they have already been faced with a very tight budget situation since the beginning of 2011. Their last line of defense is central government resources, and it appears increasingly evitable that the central government will need to step in to support investment financing during the transition period until a more durable growth model sets in.

A larger share of the pickup in investment in 2011 was financed from corporate savings (Figure 15). As such, net corporate savings fell sharply. Household savings have been relatively stable throughout the last decade. On the other hand, government net savings have been rising steadily. While this ignores growing contingent liabilities (including from an 
aging population), the current stock indicates that the government has fiscal space to support local government investment during the transition period.

Furthermore, despite the non-convertibility of the RMB, China has significant financial resources saved up as official reserves (Figure 16). While the non-sterilized component of the net foreign asset (NFA) accumulation has a counterpart in local liquidity, the sterilized component represents pure savings that can be used for any

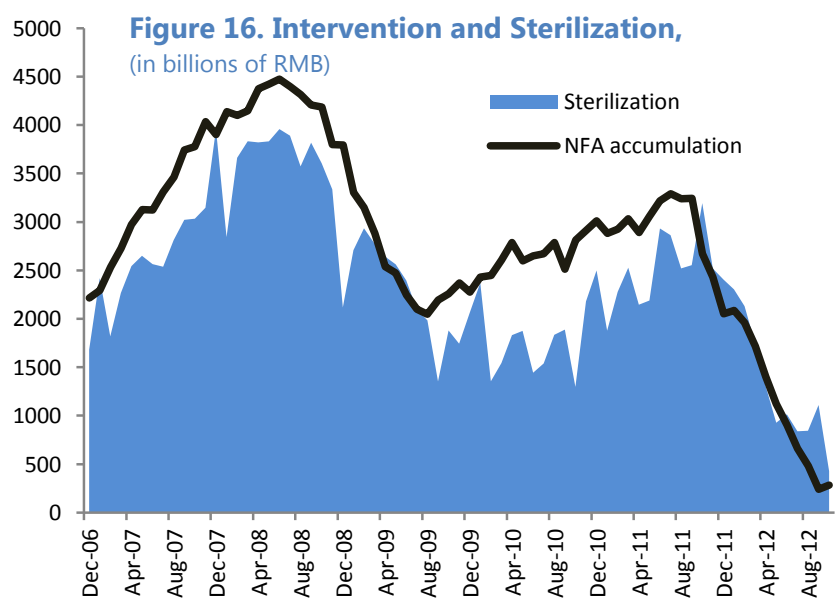
purpose both locally and abroad. The challenge is to use this remaining fiscal space wisely to ensure that China can be placed on a new footing that will ensure another decade of successful economic growth.

\section{Policy IMPlications}

As China looks ahead, ensuring strong and stable consumption will be the key to sustained growth in the coming years. By boosting productivity and raising household incomes, investment will also have a role to play, albeit diminished from the outsized influence it has been enjoying over the last decade. In the past, China's high levels of investment created capacity beyond its domestic ability to consume, but this could be absorbed outside its borders, by an exceptionally strong global economy. However, with the world economy unlikely to return to the same dizzying rates of growth and with China already a dominant global exporter, the capacity it creates will increasingly be for its domestic market.

Two things will likely have to happen: overall investment will have to be lowered and also reoriented by allowing consumption to guide what investments are made. In the past, investment was led by manufacturing, with one eye on the growing external market. Now, expanding agriculture and services - including investing in healthcare, education and financial services - are likely to be more important instead of building more factories to supply steel, cement and appliances for foreign consumers. Otherwise, if existing trends continue, valuable resources are likely to be wasted and nonperforming assets will accumulate, at a time where China's ability to finance investment is reaching its limits due to dwindling land, labor, and government resources as well as risks associated with excess liquidity.

How can policymakers ensure such a shift? Our empirical results uncover some degree of excessive investment in inland provinces. As China reduces investment over the medium term to a more sustainable consumption based growth, it needs to ensure that investment 
becomes more efficient. Coastal areas on average appear to have reached a stage where consumption is self-sustaining and not dependent on contemporary investment. Accordingly, while arguments can be made to continue for a while longer an investment-induced growth strategy in some of the poorer provinces, inland regions on average would be better off cutting their overall investment, and reorienting a reduced amount of investment that would more effectively contribute to the capital stock and lead to more enduring beneficial impacts on consumption and economic activity. In this context, we find investments in agriculture and services to be superior as a result of their more direct impact on household incomes.

This train of thought also relates to urbanization. The stages of urbanization would start with infrastructure investment, and construction of housing, putting in place the social services system, and then finally the creation of a market where further value-added will be generated and economic activity sustained. While the first two stages are relatively straightforward since this would be broadly continuing the current practice, the creation of a market will require a different set of skills that should be underpinned by transparent and simple rules for businesses. Otherwise, urbanization could lead to growth of the urban poor, which will be more difficult to tackle than rural poverty.

More generally, increasing the efficiency of investment under the current top-down allocation model will be difficult given the increasing complexity of China's economy and the uncertain nature of future growth engines amid a changing global landscape. Thus, a greater reliance on market signals would seem inevitable. This will be possible only through financial sector reform, making liberalization of this sector an urgent issue. Otherwise, if present trends continue, large deadweight losses from wasted investment will arise that could become increasingly difficult to resolve. On the other hand, cutting investment, even if it is excessive, will inevitably slow growth. Here again, the only way to maintain relatively robust growth would be to raise capital efficiency. 


\section{REFERENCES}

Bai, Chong-en, Chang-Tai Hsieh, and Yingyi Qian, 2006, "The Return to Capital in China," Brookings Papers on Economic Activity, No. 2, pp. 61-88.

Boyreau-Debray, Genevieve, and Shang-Jin Wei, 2004, "Can China Grow Faster? A Diagnosis of the Fragmentation of Its Domestic Capital Market," IMF Working Paper 04/76 (Washington DC: International Monetary Fund).

D. Qin, M. A. Gagas, P. Quising and X. He, "How Much Does Investment Drive Economic Growth in China?" Journal of Policy Modeling, Vol. 28, No. 7, 2006, pp. 751-774.

Dollar, D., and S.J. Wei, 2007, "Das (Wasted) Capital: firm Ownership and Investment Efficiency in China," IMF Working Paper 07/9 (Washington DC: International Monetary Fund).

Dong, He and Wenlang Zhang, 2010, "How dependent is the Chinese economy on exports and in what sense has its growth been export-led?", Journal of Asian Economics, 21(1), pp. 87-104.

Hurlin C. (2008), “Testing for Granger Non-causality in Heterogeneous Panels”, University of Orleans, mimeo.

Hualun Zhang, Wei Song, Xiaobao Peng, Xiaoyan Song, 2012, "Evaluate the Investment Efficiency by Using Data Envelopment Analysis: The Case of China", American Journal of Operations Research, 2012, 2, 174-182

Il Houng Lee, Xu Qingjun and Murtaza Syed, 2013, "The Middle Kingdom Grays: China's Demography and its Implications", IMF Working Paper (forthcoming), International Monetary Fund, Washington DC.

Il Houng Lee, Murtaza Syed and Liu Xueyan "Is China Over-investing and Does it Matter?", IMF Working Paper WP/12/277 (Washington DC: International Monetary Fund).

Il Houng Lee and Linghui Han, 2012, "Optimal Liquidity and Economic Stability", IMF Working Paper WP/12/135 (Washington DC: International Monetary Fund).

Qin D. and H. Y. Song, 2009, "Sources of Investment Inefficiency: The Case of Fixed-Asset Investment in China", Journal of Development Economics (90), pp. 94-105. 
Wu, Yanrui, 2008, "Has China Invested too Much? A Study of Capital Efficiency and its Determinants", Discussion Paper 36, China Policy Institute, University of Nottingham.

Xiong, Lin, 2010, “Investment Efficiency and Financial Development in China”, University of Leeds, mimeo. 